Article

\title{
Impact of Economic Freedom on the Growth Rate: A Panel Data Analysis
}

\author{
Mohammed Ershad Hussain ${ }^{1, *}$ and Mahfuzul Haque ${ }^{2}$ \\ 1 Dillard University, New Orleans, LA 70122, USA; mhussain@dillard.edu \\ 2 Scott College of Business, Indiana State University, Terre Haute, IN 47809, USA; \\ mahfuzul.haque@indstate.edu \\ * Correspondence: mhussain@dillard.edu; Tel.: +1-504-816-4271 \\ Academic Editor: Ralf Fendel \\ Received: 6 December 2015; Accepted: 21 March 2016; Published: 28 March 2016
}

\begin{abstract}
This study looks at some non-conventional determinants of economic growth, with the help of the newly developed economic freedom index datasets of the Heritage Foundation/Wall Street Journal(HF/WSJ), which is a cumulative index derived from several sub-indices (trade freedom index, financial freedom, labor freedom, business and fiscal freedom index). The cumulative economic freedom index show us how open and business friendly a country is. The sub-indices show us openness across different sector of the economy, for example, the financial sector or the trade sector etc. Traditional neo-classical economic theories have explained economic growth looking at the supply of labor, capital and state of technology, with little attention being paid to institutional factors. The study presents evidence based on two panel data-sets. The first set consists of 186 countries over the period 2013, 2014 and 2015 that show institutional factors play a crucial role in economic growth. A second data-set with data for 57 countries for the period 2004-2014 also show a positive impact on the index on the growth rate of per capita GDP.
\end{abstract}

Keywords: economic growth; freedom index; GDP; panel data

JEL Classifications: $\mathrm{O} 11 ; \mathrm{O} 38 ; \mathrm{O} 43$

\section{Introduction}

The non-economic determinants of growth rate have been under increased scrutiny in the academia in the recent past. Researchers, policy makers and governments of different countries now agree that these factors play an important role in the economic development of any country with their impact on production. Scholars believe that two countries with the same endowment of resources will prosper at different paces, if the non-economic determinants of business are different. The country with an environment more favorable to business will grow at a faster pace than the one with an environment less friendly to business.

The Heritage Foundation and The Wall Street Journal (HF/WSJ) in 1995 launched The Index of Economic Freedom, an annual index and ranking to measure the degree of economic freedom among the nations of the world. The advocates of the index took an approach similar to Adam Smith's in The Wealth of Nations, which states that "basic institutions that protect the liberty of individuals to pursue their own economic interests result in greater prosperity for the larger society" [1].

The study of the process of economic growth and the determinants of the process has in the recent past been based on the neo-classical school of economics, which puts emphasis on factor supply and the level of technology. These were the key determinants of economic growth. In the past, the role of the non-economic determinants and institutional factors of economic growth was given secondary importance. With the passage of time, scholars have realized and recognized that non-economic 
determinants also play an important role in economic growth. They define the environment under which the factors of production, labor and capital can perform. As a result, these non-economic factors play a crucial role in performance of labor and capital over time in any country. Today, it is universally believed that in countries or in cases where the non-economic determinants of economic growth (business environment) are well developed, and are more facilitating towards business, labor and capital canachieve more.

Scholars now believe that more research is needed to find the role such factors play in economic development, especially in developing countries. This will alsoenable the government, academia and policy makers to formulate appropriate policy and achieve a higher growth rate with the same quantity of resources and with the help of an improved business environment. One of the reasons for the limited research in the topic is the complexity of defining and quantifying the non-economic determinants of economic growth.

The index for 186 countries around the world for the years 2013, 2014 and 2015 has been used in this study, and focuses on different aspects of such determinants, namely, business freedom, fiscal freedom, trade freedom, labor freedom, and financial freedom, etc. We also use a composite index (HF/WSJ) called economic freedom index. It is believed that the list of factors that can be included in the non-economic factors of economic growth is longer than the variables we can propose using, but the data limitations precluded us from achieving this. These factors are difficult to measure. Many scholars believe that a single comprehensiveindex that captures all the dimensions does not exist. We believe the proxy we chose to measure this variable is effective. For example, one of the sub-indexes of the economic freedom index is trade freedom, which can be linked to the spectacular economic growth achieved by Asian Tiger countries during the 90s with the help of export-promotion policies. Under this policy, these countries provide incentives to export-promotion industries to achieve rapid growth of output, employment and income. The success of the exporting industries will then benefit the other sectors of the economy through both horizontal and vertical linkages. In the export-strategy, countries utilize their comparative advantage to stimulate the growth of the economy. This strategy links growth of the domestic economy with the world market, which creates bigger opportunity for economic growth. As a result, export oriented growth strategy can pave the way for economic integration and ensures inflow of capital and technology as foreign firms utilize the freer business environment and invest in these countries. This strategy puts emphasis on more liberal trade policy. Therefore, including this sub-index sheds light on non-economic determinants of economic growth, which cannot be captured by the traditional determinants of economic growth, namely, supply of factors and technology. In the present study, the authors focus on this area.

In the current study, we use the economic freedom index's (HF/WSJ) ${ }^{1}$ rank and score as the key independent variable and some other control variables, which include fiscal freedom index, business freedom index, labor freedom index and trade freedom index as independent variables, and several control variables. The study also examines the impact of economic freedom on the five-year GDP growth rate and the annual GDP growth rate. We first use the fixed effect panel data methodology to estimate the model with 186 countries for 2013, 2014, 2015. The second set of panel data ${ }^{2}$ we use is for 10 years (2004-2014) which includes 57 countries. In this second data set how the economic freedom of a country influences the annual growth rate of per capital GDP. Finally, we run regression on purely cross-section data-sets of 186 countries for 2013, 2014, and 2015. Again we find supporting evidence of the critical role played by economic freedom components on the annual growth rate of per-Capita GDP.

As a prelude to our study, we find the regression results yield strong evidence in support of a positive association between economic growth and the economic freedom index in both the data sets.

1 We worked with the HF/WSJ index instead of the Frazer index in the study as used previously by many researchers. The use of HF/WSJ index enabled us to compare findings with findings using Frazer index in the literature.

2 As suggested by the Referee during the review process. 
The coefficients are of the desired sign (negative for world-rank and positive for score) and they are significant in most of the estimated models. We do find evidence of a negative impact of trade freedom on economic growth. The financial freedom, business freedom, labor freedom and fiscal freedom all have a positive impact on economic growth (on both annual GDP growth and five-year GDP growth). As a result, policy makers, development partners, and the academia should all be careful when they set these policies.

This paper is structured as follows. Section 2 covers the literature review of the major papers in the field followed by Section 3 that deals with the methodology and data source. Section 4 discusses the estimation results and Section 5 presents the conclusions and policy recommendation of the paper.

\section{Literature Review}

Niclas Berggren's (2003) [2] article surveys the benefits of economic freedom for economic growth, income equality, quality of life, and human wellbeing. He pointed to several studies; (Gwartney et al., (2002) [3], Gwartney, Lawson and Holcombe (1998) [4], De Haan and Sturm (2000 [5]), Adkins, Moomaw and Savvides (2002) [6], Dawson (1998) [7], Pitlik (2002) [8]). Weede and Kampf (2002) [9] found that the level of economic freedom does not have a positive effect on economic growth, but changes in economic freedom do have such an effect on economic growth. However, other studies by Ali (1997) [10] , Easton and Walker (1997) [11], Goldsmith (1997) [12], Dawson (1998) [7], Wu and Davis (1999) [13], Hanson (2000) [14], and Heckelman (2000) [15] found a positive effect of economic freedom on the growth rate of the economy. Hall and Lawson (2014) [16] conducted an accounting of all the papers citing EWF in the high quality academic journals. The authors state that the Economic Freedom of the World (EFW) index was first produced by Gwartney, Block, and Lawson (1996) [17] and has been updated annually since then. During this period, the EFW index has been cited in hundreds of academic articles. They provide an account and description of this literature. Of 402 articles citing the EFW index, 198 used the index as an independent variable in an empirical study. Over two-thirds of these studies found economic freedom to correspond to a "good" outcome such as faster growth, better living standards, more happiness, etc. Less than $4 \%$ of the sample found economic freedom to be associated with a "bad" outcome such as increased income inequality. The balance of evidence is overwhelming that economic freedom corresponds with a wide variety of positive outcomes with almost no negative tradeoffs.

De Haan and Sturm (2000) [5] states that economic freedom underlies high levels of economic growth. Their paper compares various indicators for economic freedom and concludes that, although these measures differ somewhat in their coverage, they show similar rankings for the countries covered. Some elements in these measures are, however, questionable. The robustness of the relationship between freedom and growth was also examined and their main conclusion is that greater economic freedom fosters economic growth, but the level of economic freedom is, however, not related to growth. Carlsson and Lundstrom (2002) [18] investigated what specific types of economic freedom measures are important for growth, as most studies of the relationship between economic freedom and growth of GDP have found a positive relationship. One problem in this area they feel is the choice of economic freedom measure. A single measure does not reflect the complex economic environment and a highly aggregated index makes it difficult to draw policy conclusions. They carefully analyzed the robustness of their results since the potential problem with multicollinearity is one of the negative effects of decomposing an index. Their results show that economic freedom does matter for growth. This does not mean that increasing economic freedom, defined in general terms, is good for economic growth since some of the categories in the index are insignificant and some of the significant variables have negative effects.

Scully's (2002) [19] study investigates the role that economic freedom plays in economic growth and in the distribution in market income, the role of government policy in advancing economic progress and in promoting income equality, and the effect that the rate of economic progress has on the distribution of market income. Structural and reduced form models are estimated and they 
reveal that economic freedom promotes both economic growth and equity, and there is a positive but relatively small trade-off between growth and income inequality. Hafer (2013) [20] states that a number of studies have found that financial development and higher levels of economic freedom are associated with (cause) economic growth. According to him, the unanswered question is whether the financial development-economic growth nexus reflects influences of economic freedom operating through the financial system. His article closes that loop: it finds that countries with higher levels of initial economic freedom, on average, exhibit greater levels of financial intermediary development in subsequent years. If greater financial intermediary development engenders faster economic growth, the results of this study explain, at least partially, the observed link between economic freedom and economic growth.

Pal, Dutta and Roy's (2011) [21] study examines the effect of free media on various indicators of socio-political instability. Using a panel of 138 countries during 1994-2005. Their study shows that media free from government control and interference may decrease different forms of socio-political instability because it puts internal and external pressure on self-interested governments to act in the best interests of citizens-rather than their own. Their empirical results suggest that a freer media is associated with lower levels of socio-political instability as measured by ethnic tensions, external and internal conflicts, crime and disorder, military participation in government and religious tensions. The estimates are robust to several sensitivity tests. Williamson and Mathers (2011) [22] argues that culture, as measured by the World Values Surveys, and economic institutions associated with economic freedom are both independently important for economic prosperity, but the extent of their impact can be better understood only when both are included in the growth regression. Their results indicate that economic freedom is more important than culture for growth outcomes, suggesting substitutability between the two. They posit that culture is important for growth when economic freedom is absent and diminishes in significance once economic freedom is established. Doucouliagos and Mahmet (2006) [23] in their study apply meta-analytic techniques to the literature on the impact of economic freedom on economic growth and find an overall direct positive association between economic freedom and economic growth. An indirect positive effect of economic freedom on economic growth through the stimulation of physical capital is identified. They state that the literature is affected by specification bias with respect to controls for physical capital. The omission of physical capital results in larger estimates of the economic freedom-economic growth association. They also state that the use of panel data leads to smaller estimates of the impact of economic freedom on economic growth. The meta-analysis is confirmed by primary cross-sectional and panel data analysis of 82 countries for the period 1970-1999.

\section{Methodology and Data Source-Model Specification}

In this study, we downloaded the data from the online World Development Indicators of the World Bank and constructed a panel data for 186 countries for the years 2013, 2014 and 2015. We use the economic freedom index, fiscal freedom index, business freedom index, labor freedom index, and trade freedom index as independent variables. The data are downloaded from HF/WSJ (http://www.heritage.org/index/). As an alternative, we use the annual growth rate of Gross Domestic Product (GDP) and the five-year GDP growth rate as the dependent variables in our study.

We run different versions of the following model and report results in the tables presented at the end of the article. We discuss and examine the results in the following section.

We define the model as (Equation (1)):

Annual GDP Growth Rate $=f($ Economic Freedom Index, Controls, Financial Freedom Index, Business Freedom Index, Fiscal Freedom Index, Trade Freedom Index, Labor Freedom Index ) 
In Table 3, we include only the value of the index (score or world rank) of the countries because this is the base model. In Tables 4 and 5 we use the index and two other sub-indices, namely, Trade Freedom Index and Financial Freedom Index. In Tables 6 and 7 we add three more indexes, namely, the Business Freedom Index, the Labor Freedom Index, and the Fiscal Freedom Index. In Table 9, we estimate a simple cross-section and get three sets of results for 2013, 2014, and 2015, respectively.

We use the panel data fixed effect model with the countries as the panel unit and 2013, 2014 and 2015 as the time unit. Due to the large number of countries included in the sample (186 countries), we need to use panel data methods to estimate the models. Hence, we adopt the fixed effect model in the present study to account for country dummy variables.

In the next phase of the study, we form a second data-set including 57 countries for the time period 2004-2014 3 and run a random effect model (we also run the fixed effect model and then use the Hausman test) to get our result. Hausman test indicates that we prefer the random effect model. We use the HF/WSJ index and the data from World Bank again.

The model is given below (Equation (2)):

Per Capita GDP Growth Rate $=f($ Economic Freedom Index, Export of Goods, Life Expectancy, Lower - secondary Enrollment, Foreign Investment)

In Table 8, we use three control variables, including Export of Goods as percentage of GDP, Life Expectancy, Lower Secondary Enrollment, and Foreign Direct Investment as Percentage of GDP. We wanted to control for these dimensions of development as we focused on the impact of economic freedom on growth. More and more researchers are using these variables as controls for growth equations.

\section{Results}

In Table 1, we present the summary statistics for the variables included in this study. Annual GDP growth rate has a mean of 3.58 percent per year. The five-year GDP growth rate has a mean of 3.19 percent per year. The economic freedom index has a mean score of 57.53 with a minimum of 1 and a maximum of 90.1. Summary statistics for the trade freedom index, financial freedom index, business freedom index, labor freedom and fiscal freedom indices are also reported in this table.

Table 1. Summary statistics of important variables.

\begin{tabular}{cccccc}
\hline Variable & Observation & Mean & Standard Deviation & Min & Max \\
\hline GDP growth rate & 556 & 3.58 & 6.44 & -61 & 104.5 \\
5 Year GDP growth rate & 552 & 3.19 & 3.13 & -14.7 & 16.6 \\
score1 & 557 & 57.53 & 16.55 & 0 & 90.1 \\
Trade freedom index & 557 & 72.77 & 17.51 & 0 & 90 \\
Financial freedom index & 557 & 47.27 & 20.70 & 0 & 90 \\
Business freedom & 557 & 63.65 & 18.43 & 0 & 100 \\
Labor freedom & 557 & 60.50 & 18.19 & 0 & 98.5 \\
Fiscal freedom & 557 & 75.51 & 17.96 & 0 & 99.9 \\
\hline
\end{tabular}

In Table 2, we present the correlation of the important variables included in the model. The two most important variables are the annual GDP growth rate and the economic freedom index, which have a correlation coefficient of -0.0687 . This implies that these two variables are inversely associated with one another. In the case of the five-year GDP growth rate, we also find the correlation coefficient of -0.1058 . This is a surprising result. This means that the higher the economic freedom in a country, the lower the annual GDP growth rate. The trade freedom index, the financial freedom index, and

3 We followed the suggestion for increasing the time span of the data period by the anonymous referee. 
the business freedom index also have a negative correlation with the annual GDP growth rate. We find a similar correlation with these three types of freedom indexes and the five-year GDP growth rate. However, if we consider the association of the annual and five-year GDP growth rate vis-à-vis labor freedom and fiscal freedom, we find a positive association.

Table 2. Correlation of Important Variables.

\begin{tabular}{|c|c|c|c|c|c|c|c|c|}
\hline & $\begin{array}{l}\text { GDP } \\
\text { Growth } \\
\text { Rate }\end{array}$ & $\begin{array}{c}5 \text { Year GDP } \\
\text { Growth } \\
\text { Rate }\end{array}$ & $\begin{array}{l}\text { Freedom } \\
\text { Score1 }\end{array}$ & $\begin{array}{l}\text { Trade } \\
\text { Freedom } \\
\text { Index }\end{array}$ & $\begin{array}{l}\text { Financial } \\
\text { Freedom } \\
\text { Index }\end{array}$ & $\begin{array}{l}\text { Business } \\
\text { Freedom }\end{array}$ & $\begin{array}{l}\text { Labor } \\
\text { Freedom }\end{array}$ & $\begin{array}{l}\text { Fiscal } \\
\text { Freedom }\end{array}$ \\
\hline GDP growth rate & 1 & & & & & & & \\
\hline Freedom score1 & -0.0687 & -0.1058 & 1 & & & & & \\
\hline $\begin{array}{l}\text { Financial } \\
\text { freedom index }\end{array}$ & -0.1139 & -0.2871 & 0.7806 & 0.6574 & 1 & & & \\
\hline Business freedom & -0.0366 & -0.189 & 0.6844 & 0.4535 & 0.5868 & 1 & & \\
\hline Labor freedom & 0.09 & 0.0205 & 0.4444 & 0.196 & 0.2562 & 0.5165 & 1 & \\
\hline Fiscal freedom & 0.241 & 0.2615 & 0.3991 & 0.3148 & 0.1008 & 0.2064 & 0.2991 & 1 \\
\hline
\end{tabular}

In Table 3, we present regression results with the entire data-set. As we have already pointed out, here we use two measures of GDP growth rate: the annual GDP growth rate and the five-year average GDP growth rate. In panel a, we use five-year GDP growth rate as the dependent variable and the world rank of economic freedom as the independent variable. We find that the coefficient of world rank is negative and significant (the coefficient is -0.025 and it is significant at the 5 percent level), and this is a desirable result. However, in panel $b$, we find that the five-year GDP growth rate is positively associated with the freedom index score (the coefficient is 0.12 and it is significant at the 5 percent level). This means that if a country is open, the higher the annual growth rate will be. We deduce that in the five years we measured, economic freedom indeed had a beneficial impact on the growth rate of GDP. In panels $\mathrm{c}$ and d, we run similar regressions with the annual GDP growth rate as the dependent variable and find a similar result. The coefficients of the freedom index however are not significant. The sub-indices we use in the models-namely, trade freedom index and financial freedom index-have correlation with the overall score. The base model is the model of Table 3 where we use the freedom index alone and find a similar result. Therefore, Tables 4 and 7 are all testing extensions of the base model in Table 3. Even if we have multicollinearity among the independent variables, that does not change the main results of Table 3. Correlation does not mean causation in this case. For instance, in Table 3, the two sub-indexes represent two very different dimensions of economic freedom, namely trade and financial freedom. Though many countries undertake these reforms concurrently (under a comprehensive economic reform package), one can be associated with the other, however, one reform will not cause the other. The same applies to the other indices of Tables 4-7. Another point of view is that countries with an improved trade regime tend to have an improved financial sector also. That may make the freedom indexes correlated also.

In Table 4, we use the five-year GDP growth rate as the dependent variable and several independent variables. This is the expansion model based on Table 3. In panel a, we use the world rank of economic freedom, trade freedom index, financial freedom index as the independent variables, we find a negative coefficient for the rank of economic freedom ( the coefficient is -0.037 significant at the 1 percent level).

In panel b, of Table 4, we replace the world-rank of the freedom index with the score of freedom index as the dependent variable. All the independent variables, remain the same as those of panel a. We find that the coefficient is 0.179 and it is significant at the 1 percent level. This shows that a higher rank in the economic freedom are positively associated with the five-year GDP growth. In the last row of the table, we report the R-square, number of observations, and F-statistics. We repeat the same for all the tables that will follow. 
Table 3. Simple Model: 5 Year GDP Growth Rate and Annual GDP Growth rate are dependent variables (Equation (1)).

\begin{tabular}{|c|c|c|c|c|}
\hline $\begin{array}{l}\text { Year GDP Growth } \\
\text { Rate/Annual GDP } \\
\text { Growth Rate }\end{array}$ & Coefficient & Standard Errors & $T$-Statistics & $p$-Value \\
\hline \multicolumn{5}{|c|}{$\begin{array}{l}\text { Panel a: World-rank Index is Independent Variable } \\
5 \text { Year GDP Growth Rate is the Dependent Variable }\end{array}$} \\
\hline $\begin{array}{c}\text { Freedom worldrank1 } \\
\text { constant } \\
R \text {-square }=0.1113\end{array}$ & $\begin{array}{l}-0.025 \\
5.304\end{array}$ & $\begin{array}{c}0.011 \\
0.990 \\
\text { F-test }=4.57\end{array}$ & $\begin{array}{l}-2.140 \\
5.360\end{array}$ & $\begin{array}{c}0.033 \\
0.000 \\
\text { Observation }=552\end{array}$ \\
\hline \multicolumn{5}{|c|}{$\begin{array}{l}\text { Panel b: Score-rank Index is Independent Variable } \\
5 \text { Year GDP Growth Rate is the Dependent Variable }\end{array}$} \\
\hline $\begin{array}{c}\text { Freedom score1 } \\
\text { Constant } \\
R \text {-square }=0.0112\end{array}$ & $\begin{array}{c}0.120 \\
-3.778\end{array}$ & $\begin{array}{c}0.052 \\
2.984 \\
\text { F-test }=5.46\end{array}$ & $\begin{array}{c}2.340 \\
-1.270\end{array}$ & $\begin{array}{c}0.020 \\
0.206 \\
\text { Observation }=552\end{array}$ \\
\hline \multicolumn{5}{|c|}{$\begin{array}{l}\text { Panel c: World-rank Index is Independent Variable } \\
\text { Annual GDP Growth Rate }\end{array}$} \\
\hline $\begin{array}{c}\text { Freedom worldrank1 } \\
\text { constant } \\
R \text {-square }=0.0117\end{array}$ & $\begin{array}{l}-0.067 \\
9.288\end{array}$ & $\begin{array}{c}0.069 \\
5.948 \\
\text { F-test }=0.92\end{array}$ & $\begin{array}{l}-0.960 \\
1.560\end{array}$ & $\begin{array}{c}0.337 \\
0.119 \\
\text { Observation }=556\end{array}$ \\
\hline $\begin{array}{c}\text { Freedom score1 } \\
\text { Constant } \\
R \text {-square }=0.0025\end{array}$ & $\begin{array}{c}0.166 \\
-5.990\end{array}$ & $\begin{array}{c}0.313 \\
18.051 \\
\text { F-test }=0.28\end{array}$ & $\begin{array}{c}0.530 \\
-0.330\end{array}$ & $\begin{array}{c}0.596 \\
0.740 \\
\text { Observation }=556\end{array}$ \\
\hline
\end{tabular}

Table 4. Extended Model One: 5 Year GDP Growth Rate is dependent variable.

\begin{tabular}{|c|c|c|c|c|}
\hline Year GDP Growth Rate & Coefficient & Standard Errors & $T$-Statistics & $p$-Value \\
\hline \multicolumn{5}{|c|}{ Panel a: World-rank Index is the Independent Variable } \\
\hline Freedom worldrank1 & -0.037 & 0.012 & -3.190 & 0.002 \\
\hline Trade freedom index & -0.060 & 0.012 & -5.190 & 0.000 \\
\hline Constant & 12.074 & 2.239 & 5.390 & 0.000 \\
\hline$R$-square $=0.0251$ & & $F$-test $=19.33$ & & Observation $=552$ \\
\hline \multicolumn{5}{|c|}{ Panel b: Score-rank Index is the Independent Variable } \\
\hline Financial freedom index & -0.025 & 0.031 & -0.810 & 0.417 \\
\hline Constant & -1.489 & 3.047 & -0.490 & 0.625 \\
\hline$R$-square $=0.0004$ & & $F$-test $=11.45$ & & Observation $=552$ \\
\hline
\end{tabular}

Table 5. Extended Model One: Annual GDP Growth Rate is the dependent variable.

\begin{tabular}{|c|c|c|c|c|}
\hline $\begin{array}{l}\text { Annual GDP Growth } \\
\text { Rate }\end{array}$ & Coefficient & Standard Errors & $T$-Statistics & $p$-Value \\
\hline \multicolumn{5}{|c|}{ Panel a: World-rank Index is Independent Variable } \\
\hline Freedom worldrank1 & -0.179 & 0.061 & -2.950 & 0.003 \\
\hline Financial freedom index & -0.079 & 0.167 & -0.480 & 0.634 \\
\hline Constant & 69.389 & 11.403 & 6.090 & 0.000 \\
\hline$R$-square $=0.0065$ & & $F$-test $=51.2$ & & Observation $=552$ \\
\hline Trade freedom index & -0.640 & 0.052 & -12.270 & 0.000 \\
\hline Financial freedom index & -0.050 & 0.166 & -0.300 & 0.765 \\
\hline Constant & 11.572 & 16.105 & 0.720 & 0.473 \\
\hline$R$-square $=0.0304$ & & $F$-test $=50.33$ & & Observation $=556$ \\
\hline
\end{tabular}

Table 6. Extended Model Two: 5 Year GDP Growth Rate is the dependent variable.

\begin{tabular}{ccccc}
\hline Variables & Coefficient & Standard Errors & T-Statistics & $p$-Value \\
\hline \multicolumn{4}{c}{ Panel a: World-rank Index is the Independent Variable } \\
\hline Freedom world rank & -0.013 & 0.012 & -1.030 & 0.302 \\
Trade Freedom & -0.036 & 0.013 & -2.840 & 0.005 \\
Financial Freedom & -0.015 & 0.031 & -0.480 & 0.633 \\
Business Freedom & 0.058 & 0.016 & 2.660 & 0.000 \\
Labor Freedom & 0.026 & 0.011 & 0.143 \\
Fiscal Freedom & 0.009 & 0.006 & 0.599 \\
Constant & 1.553 & F-test $=10.77$ & 0.530 & Observation $=552$ \\
R-square $=0.21$ & & & & \\
\hline
\end{tabular}


Table 6. Cont.

\begin{tabular}{|c|c|c|c|c|}
\hline Variables & Coefficient & Standard Errors & $T$-Statistics & $p$-Value \\
\hline Freedom score1 & 0.046 & 0.059 & 0.780 & 0.434 \\
\hline Business Freedom index & 0.060 & 0.016 & 3.710 & 0.000 \\
\hline Labor Freedom index & 0.025 & 0.012 & 2.070 & 0.039 \\
\hline Fiscal Freedom index & 0.010 & 0.006 & 1.480 & 0.139 \\
\hline
\end{tabular}

Note: The VIF of panel (a) are: VIF of Financial Freedom is 3.1, World rank is 2.43, Business Freedom is 2.23,

Trade Freedom is 2.19, Labor Freedom is 1.54, and Fiscal Freedom is 1.33; The VIF of panel (b) are: VIF of

Financial Freedom is 3.13, score is 5.84, Business Freedom is 2.22, Trade Freedom is 2.70, Labor Freedom is 1.55,

Fiscal Freedom is 1.41.

Table 7. Extended Model Two: Annual GDP Growth Rate is the dependent variable.

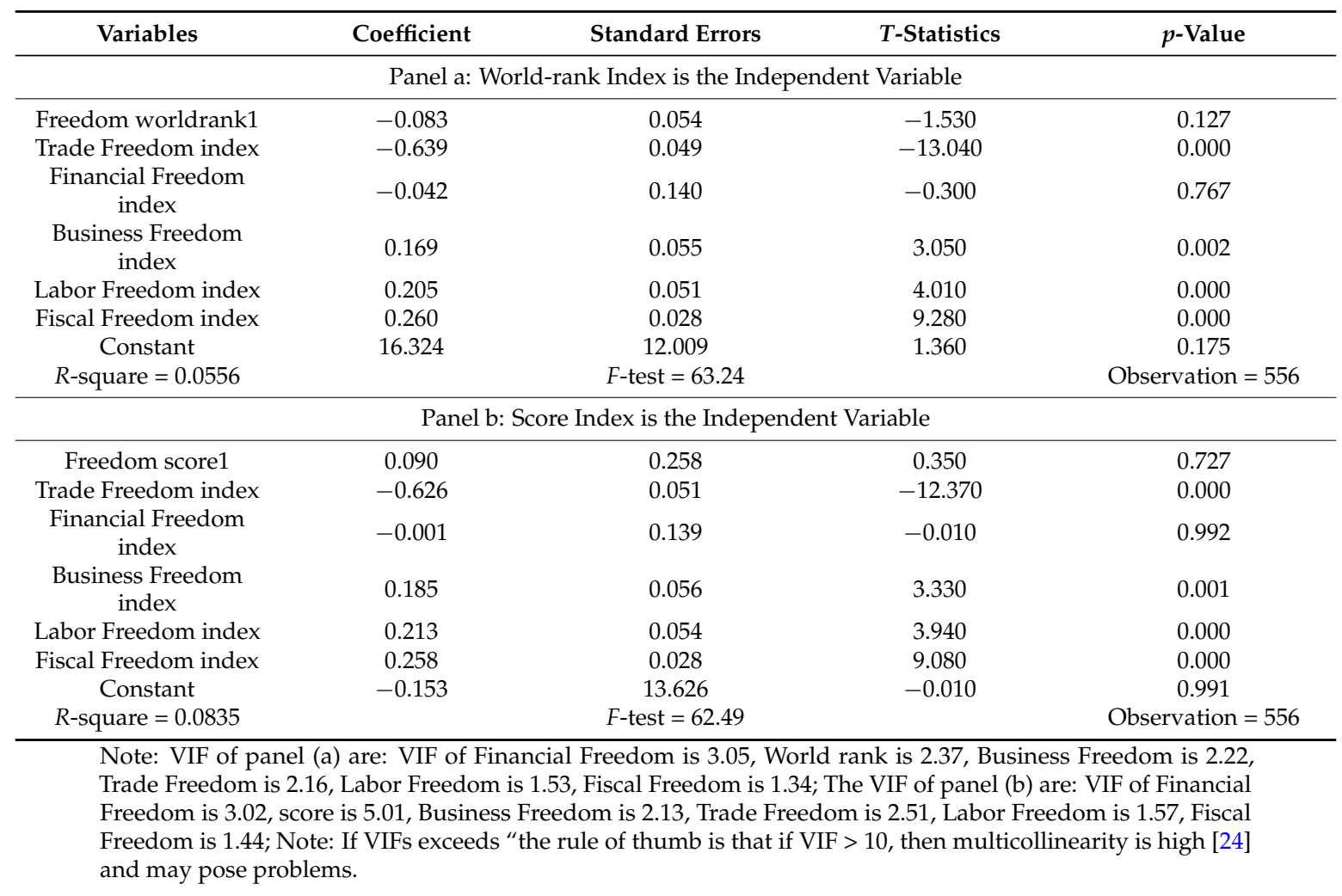

In Table 5, we use the annual GDP growth rate as the dependent variable, with a number of independent variables. We include world rank (panel a) or world score (panel b), trade freedom, and financial freedom. In panel a, we find that the coefficient of the world rank of economic freedom is negatively associated with the annual GDP growth rate (significant at the 1 percent level). In panel $b$, we find that the coefficient of freedom score is positive but significant at the 1 percent level. We also find that the coefficient of the trade freedom index is negative and significant in both panels, which implies that liberal trade freedom hinders the annual growth rate of GDP. Again, we report the number of observations, R-square and F-statistics for each model.

In Table $6^{4}$, we estimate a model with the five-year GDP growth rate as the dependent variable. Again, in panel a, we use the freedom world-rank and panel $b$ has freedom score. We use a host of other

4 We also ran regression with per capital GDP as one of the independent variables in the models of Tables 6 and 7. The coefficients of the variable were not significant. 
independent variables here: trade freedom, financial freedom, business freedom, labor freedom, and fiscal freedom. In both panel $a$ and $b$, the coefficients of the freedom index are insignificant. In panel a, trade freedom index, business freedom index, and labor freedom index have positive and significant coefficients. In panel $b$, only the trade freedom index has negative and significant coefficients. The business freedom index and labor freedom index have positive coefficients. For Tables 4 and 6 we use the five-year GDP growth rate as the dependent variable. This dependent variable may cause ambiguities in terms of how the index for one year may affect GDP for the previous year. Alternately, in Tables 3, 5 and 7 we use annual GDP growth rate as the dependent variable. We put more emphasis on the results in Tables 3 and 5 and Table 7, while using Tables 4 and 6 as a guide.

In Table $7^{5}$, we repeat the models used in Table 6 , but change the five-year GDP growth rate (dependent variable) with annual GDP growth rate. We find similar results as those of Table 6. We now find evidence that fiscal freedom index have positive and significant coefficient in both panels. Overall, we do find evidence that the economic freedom index (put in world-rank or score) does have an important role in the economic growth of a country.

In Table 8, we present the model with the new data set for 10 years (2004-2014) for 57 countries around the world. We run fixed effect regression and find that the index has a positive impact on the annual growth rate of per capita GDP in 2005 with constant \$. This shows that although traditional economic models do now place emphasis on the non-economic factors or institutional factors, these factors indeed play an important role in the economic growth of a country. This is panel data evidence and should be applicable to many different countries.

Table 8. The Fixed and the Random Effects Model (2004-2014 data-set-Equation (2)).

\begin{tabular}{|c|c|c|c|c|}
\hline $\begin{array}{l}\text { Per Capita GDP Growth } \\
\text { Rate ( Constant } 2005 \$ \text { ) }\end{array}$ & Coefficient & Standard Errors & $T$-Statistics & $p$-Value \\
\hline \multicolumn{5}{|c|}{ Fixed Effect Model } \\
\hline Freedom Score & 1.110 & 0.368 & 3.020 & 0.003 \\
\hline Export as $\%$ of GDP & -0.424 & 0.398 & -1.070 & 0.287 \\
\hline Life Expectancy & 0.021 & 0.142 & 0.150 & 0.881 \\
\hline $\begin{array}{l}\text { Lower Secondary } \\
\text { Enrollment }\end{array}$ & 0.014 & 0.087 & 0.170 & 0.869 \\
\hline $\begin{array}{c}\text { Foreign Direct Investment } \\
\text { as } \% \text { of GDP }\end{array}$ & -0.146 & 0.086 & -1.700 & 0.09 \\
\hline $\begin{array}{c}\text { Constant } \\
R \text {-square }=0.007\end{array}$ & -49.243 & $\begin{array}{c}32.130 \\
F \text {-test }=2.76\end{array}$ & -1.530 & $\begin{array}{c}0.126 \\
\text { Observation }=615\end{array}$ \\
\hline \multicolumn{5}{|c|}{ Random Effect Model } \\
\hline Freedom Score & 1.098 & 0.273 & 4.020 & 0.000 \\
\hline Export as \% of GDP & 0.040 & 0.135 & 0.290 & 0.769 \\
\hline Life Expectancy & 0.071 & 0.134 & 0.530 & 0.595 \\
\hline $\begin{array}{l}\text { Lower Secondary } \\
\text { Enrollment }\end{array}$ & -0.022 & 0.075 & -0.290 & 0.770 \\
\hline $\begin{array}{c}\text { Foreign Direct Investment } \\
\text { as } \% \text { of GDP }\end{array}$ & -0.075 & 0.062 & -1.210 & 0.224 \\
\hline $\begin{array}{c}\text { Constant } \\
R \text {-square }=0.0484\end{array}$ & -72.671 & $\begin{array}{c}18.099 \\
\text { Wald-Cai-Sq }=20.22\end{array}$ & -4.020 & $\begin{array}{c}0.000 \\
\text { Observation }=615\end{array}$ \\
\hline
\end{tabular}

In Table 9, we present estimation results for each year separately-namely, 2013, 2014 and 2015-where we have data for all 186 countries for those years (we divide the pool data set into three separate cross-sections based on the years 2013, 2014, and 2015). Our intention here is to compare our result with that of Tables 3 and 7 where we use these three data-set as a pool set. We find support for

5 As suggested by the anonymous Referee, we also checked for multicollinearity and found no problem regarding this issue. The estimates obtained from VIF findings for our study are good. 
our earlier findings in Tables 3 and 7 and conclude that economic freedom has a significant impact on annual GDP growth rate for all 186 countries.

Table 9. Cross Section Evidence from 2013, 2014, and 2015.

\begin{tabular}{|c|c|c|c|c|}
\hline Variables & Coefficient & Standard Error & $T$-Statistics & $p$-Value \\
\hline \multicolumn{5}{|c|}{2015} \\
\hline Freedom Score & 0.070 & 0.033 & 2.090 & 0.038 \\
\hline Tradefreedom & -0.002 & 0.028 & -0.060 & 0.956 \\
\hline Financial freedom & -0.061 & 0.024 & -2.560 & 0.011 \\
\hline constant & 1.986 & 1.433 & 1.390 & 0.167 \\
\hline & $N=186$ & $R$-square $=0.039$ & $F$-stat $=2.45$ & \\
\hline \multicolumn{5}{|c|}{2014} \\
\hline Freedom Score & 0.234 & 0.045 & 5.220 & 0.000 \\
\hline Trade freedom & -0.115 & 0.037 & -3.060 & 0.003 \\
\hline Financial freedom & -0.081 & 0.033 & -2.430 & 0.016 \\
\hline constant & 2.602 & 2.067 & 1.260 & 0.210 \\
\hline & $N=184$ & $R$-square $=0.014$ & $F$-stat $=9.47$ & \\
\hline \multicolumn{5}{|c|}{2013} \\
\hline Freedom Score & -0.046 & 0.066 & -0.690 & 0.488 \\
\hline Trade freedom & -0.145 & 0.052 & -2.790 & 0.006 \\
\hline Financial freedom & 0.036 & 0.043 & 0.840 & 0.400 \\
\hline \multirow{2}{*}{ constant } & 15.322 & 2.413 & 6.350 & 0.000 \\
\hline & $N=186$ & $R$-square $=0.116$ & $F$-stat $=7.97$ & \\
\hline
\end{tabular}

If we now analyze the results from Tables 3-8 we observe that there is very consistent and clear evidence that economic freedom has a significant impact on the annual GDP growth rate across different models, sample of countries and periods under consideration. Therefore, traditional economic theory needs to make room for the importance of such factors in the process of economic growth.

\section{Conclusions}

In this study, we investigate the impact of economic freedom on five-year GDP growth rate and annual GDP growth rate and find strong evidence in support of a positive association between the growth rate (measured alternately with annual growth rate and five-year growth rate) and the economic freedom index. The coefficients are of the desired sign (negative for world-rank and positive for score) and they are significant in most of the estimated models. The neo-classical growth models based on production function do not account for one very important determinant of economic growth, namely, the economic freedom of a country. Those models only account for labor, capital and technology. Therefore, the external business environment and non-economic factors play an important role in the economic prosperity of any country. Adam Smith had recognised the importance of these factors ahead of time when he pointed out that "... the liberty of individuals to pursue their own economic interests ... " For example, corruption, rules and regulations, rule of law, political stability, business friendly environment etc. are crucial determinants of economic growth.

We do find evidence of a positive and strong impact of trade freedom on economic growth. The financial freedom, business freedom, labor freedom and fiscal freedom all have a positive impact on economic growth (on both annual GDP growth and five-year GDP growth). These results of the fixed effect panel data model (control of country and time) make the results applicable and appropriate for other countries also. In order to support the evidence presented earlier, we prepared a second data set with 53 countries for 10 years (2004-2014) and find clear evidence of a positive impact of economic freedom index on the annual growth rate of per capita GDP in constant $2005 \$$. We used the random effect model (panel data methodology) suggesting that this conclusion can be used broadly. 
We recommend that policy makers, multinational donor agencies, and academia should consider these non-economic factors as important determinants of economic growth. Policies and programs to improve this aspect of the business environment should be carefully designed, timed, coordinated and implemented. The role of non-economic factors should be at the center of any analysis and not be placed on the side line as has happened in the past. A country cannot achieve and sustain rapid economic progress without a developed economic environment. If such policies and programs are successful, they can go a long way to ensuring economic success. The quality of life of millions of poor people in many developing countries depends on the key role of such non-economic factors. Addressing non-economic factors should be considered to be an essential tool in the fight against hunger, poverty and malnutrition anywhere in the world. Since economic freedom needs to be achieved in different sectors (such as trade, financial sector, fiscal, etc.) of the economy, an inclusive policy to address issues in different sectors should be designed and implemented to achieve good results. Reforms in these various sectors can yield synergies, and if successful, can boost economic growth for many years to come.

Supplementary Materials: The following are available online at http:/ /www.mdpi.com/2227-7099/4/2/5/s1, Table S1: 186 countries for the period 2013, 2014, 2015 in the older data-set used in Equation (1); Table S2: 57 countries for the period 2004-2014 newer data set used in Equation (2).

Acknowledgments: The authors gratefully acknowledge the comments and the helpful suggestions from the two anonymous referees and thank them. Thanks also goes to the editor. The usual disclaimer applies.

Author Contributions: Both authors contributed equally.

Conflicts of Interest: The authors declare no conflict of interest.

\section{Appendix I: EFI Components}

The Index of Economic Freedom is an annual index and ranking created by The Heritage Foundation, and The Wall Street Journal in 1995 has given the following description of the index [25-27].

The Index's 2008 definition of economic freedom is 'The highest form of economic freedom provides an absolute right of property ownership, fully realized freedoms of movement for labor, capital, and goods, and an absolute absence of coercion or constraint of economic liberty beyond the extent necessary for citizens to protect and maintain liberty itself'.

The index scores nations on 10 broad factors of economic freedom using statistics from organizations like the World Bank, the International Monetary Fund and the Economist Intelligence Unit:

Business Freedom: Business freedom is a quantitative measure of the ability to start, operate, and close a business that represents the overall burden of regulation as well as the efficiency of government in the regulatory process.

Trade Freedom: Trade freedom is a composite measure of the absence of tariff and non-tariff barriers that affect imports and exports of goods and services. Different imports entering a country can, and often do, face different tariffs.

Monetary Freedom: Monetary freedom combines a measure of price stability with an assessment of price controls. Both inflation and price controls distort market activity. Price stability without microeconomic intervention is the ideal state for the free market.

Government Size/Spending: This component considers the level of government expenditures as a percentage of GDP. Government expenditures, including consumption and transfers, account for the entire score.

Fiscal Freedom: Fiscal freedom is a measure of the tax burden imposed by government.

Property Rights: The property rights component is an assessment of the ability of individuals to accumulate private property, secured by clear laws that are fully enforced by the state. 
Investment Freedom: In an economically free country, there would be no constraints on the flow of investment capital. Individuals and firms would be allowed to move their resources into and out of specific activities internally and across the country's borders without restriction.

Financial Freedom: Financial freedom is a measure of banking efficiency as well as a measure of independence from government control and interference in the financial sector.

Freedom from Corruption: Corruption erodes economic freedom by introducing insecurity and uncertainty into economic relationships. The higher the level of corruption, the lower the level of overall economic freedom and the lower a country's score.

Labor Freedom: The labor freedom component is a quantitative measure that looks into aspects of the legal and regulatory framework of a country's labor market.

For analytical understanding and presentational clarity, the 10 economic freedoms are grouped into four broad categories of economic freedom:

- Rule of law (property rights, freedom from corruption);

- Government size (fiscal freedom, government spending);

- Regulatory efficiency (business freedom, labor freedom, monetary freedom); and

- Market openness (trade freedom, investment freedom, financial freedom).

Ranked countries are given a score ranging from 0 to 100 for each of the 10 components of economic freedom, and these scores are then averaged (using equal weights) to compute the country's final economic freedom score. In addition to the scores, the country pages include in each case a brief introduction describing the economic strengths and weaknesses and the political and economic background influencing a country's performance, as well as a statistical profile documenting the country's main economic indicators.

Meaning

The Heritage Foundation reports that the top $20 \%$ on the index have twice the per capita income of those in the second quintile, and five times that of the bottom 20\%. Carl Schramm, who wrote the first chapter of the 2008 Index, states that cities of Medieval Italy and mid-19th century Midwestern American cities all flourished to the degree they possessed economic fluidity and institutional addictiveness created by economic freedom.

According to Will Wilkinson of the libertarian think tank Cato Institute, studies show that higher economic freedom correlates strongly with higher self-reported happiness. According to economists Tomi Ovaska and Ryo Takashima, economic freedom research suggests "that people unmistakably care about the degree to which the society where they live provides them opportunities and the freedom to undertake new projects, strongly with and make choices based on one's personal preferences."

According to the Cato Institute, higher economic freedom promotes participation and collaboration. Also claimed is that higher economic freedom is extremely significant in preventing wars; according to their calculations, freedom is around 54 times more effective than democracy (as measured by Democracy Score) in diminishing violent conflict.

\section{Appendix II: EFI Components}

Berggren, Niclas (2003) [2] described the EFI index and its components in the following way: Note: GCR_Global Competitiveness Report; ICRG_ International Country Risk Guide

\section{Size of Government: Expenditures, Taxes, and Enterprises}
A. General government consumption spending as a percentage of total consumption
B. Transfers and subsidies as a percentage of GDP
C. Government enterprises and investment as a percentage of GDP
D. Top marginal tax rate (and income threshold to which it applies) 


\section{Legal Structure and Security of Property Rights}

A. Judicial independence: The judiciary is independent and not subject to interference by the government or parties in disputes (GCR)

B. Impartial courts: A trusted legal framework exists for private businesses to challenge the legality of government actions or regulation (GCR)

C. Protection of intellectual property (GCR)

D. Military interference in rule of law and the political process (ICRG)

E. Integrity of the legal system (ICRG)

\section{Access to Sound Money}

A. Average annual growth of the money supply in the past five years minus average annual growth of real GDP in the past ten years

B. Standard inflation variability in the past five years

C. Recent inflation rate

D. Freedom to own foreign-currency bank accounts domestically and abroad

\section{Freedom to Exchange with Foreigners}

A. Taxes on international trade

i. Revenue from taxes on international trade as a percentage of exports plus imports

ii. Mean tariff rate

iii. Standard deviation of tariff rates

B. Regulatory trade barriers

i. Hidden import barriers: no barriers other than published tariffs and quotas (GCR)

ii. Costs of importing: the combined effect of import tariffs, license fees, bank fees, and the time required for administrative red tape raises

C. Actual size of trade sector compared to expected size

D. Difference between the official exchange rate and the black-market rate

E. International capital market controls

i. Access of citizens to foreign capital markets and foreign access to domestic capital markets (GCR)

ii. Restrictions on the freedom of citizens to engage in capital-market exchange with foreigners' index of capital controls among thirteen IMF categories

\section{Regulation of Credit, Labor, and Business}

\section{A. Credit-Market Regulations}

i. Ownership of banks: percentage of deposits held in privately owned banks

ii. Competition: Domestic banks face competition from foreign banks (GCR)

iii. Extension of credit: percentage of credit extended to private sector

iv. Avoidance of interest-rate controls and regulations that lead to negative real interest rates

v. Interest-rate controls: Interest-rate controls on bank deposits or loans or both are freely determined by the market (GCR)

B. Labor-Market Regulations

i. Impact of minimum wage: the minimum wage, set by law, has little impact on wages because it is too low or not obeyed (GCR)

ii. Hiring and firing practices of companies determined by private contract (GCR)

iii. Share of labor force whose wages are set by centralized collective bargaining (GCR)

iv. Unemployment benefits system preserves the incentive to work (GCR)

v. Use of conscripts to obtain military personnel 


\section{Business Regulations}

i. Price controls: the extent to which businesses are free to set their own prices

ii. Administrative conditions and new businesses: administrative procedures is an important obstacle to starting a new business (GCR)

iii. Time that senior management spends dealing with government bureaucracy (GCR)

iv. Starting a new business is generally easy (GCR)

v. Irregular, additional payments connected with import and export permits, business licenses, exchange controls, tax assessments, police protection, or loan applications are very rare (GCR)

\section{References}

1. 2016 Index of Economic Freedom. Available online: http:/www.heritage.org/index/ranking (accessed on 23 March 2016).

2. Berggren, N. The Benefits of Economic Freedom: A Survey. Indep. Rev. 2003, 8, 192-211.

3. Gwartney, J.D.; Lawson, R.; Edwards, C.; Park, W.; De Rugy, V.; Wagh, S. Economic Freedom of the World: 2002 Annual Report, 6th ed.; Fraser Institute: Vancouver, BC, Canada, 2002.

4. Gwartney, J.G.; Lawson, R.A.; Holcombe, R.G. The Size and Functions of Government and Economic Growth; Joint Economic Committee: Washington, DC, USA, 1998; Available online: http:/ / frihetspartiet.net/function.pdf (accessed on 23 March 2016).

5. De Haan, J.; Sturm, J. On the relationship between economic freedom and economic growth. Eur. J. Polit. Econ. 2000, 16, 215-241. [CrossRef]

6. Adkins, L.C.; Moomaw, R.L.; Savvides, A. Institutions, Freedom, and Technical Efficiency. South. Econ. J. 2002, 69, 92-108. [CrossRef]

7. Dawson, J.W. Institutions, Investment, and Growth: New Cross-Country and Panel Data Evidence. Econ. Inq. 1998, 36, 603-619. [CrossRef]

8. Pitlik, H. The Path of Liberalization and Economic Growth. Kyklos 2002, 55, 57-80. [CrossRef]

9. Weede, E.; Kämpf, S. The Impact of Intelligence and Institutional Improvements on Economic Growth. Kyklos 2002, 55, 361-380. [CrossRef]

10. Ali, A. Economic Freedom, Democracy, and Growth. J. Priv. Enterp. 1997, 13, 1-20.

11. Easton, S.T.; Walker, M.A. Income, Growth, and Economic Freedom. Am. Econ. Rev. 1997, 87, $328-332$.

12. Goldsmith, A.A. Economic Rights and Government in Developing Countries: Cross-National Evidence on Growth and Development. Stud. Comp. Int. Dev. 1997, 32, 29-44. [CrossRef]

13. Wu, W.; Davis, O.A. The Two Freedoms, Economic Growth and Development: An Empirical Study. Public Choice 1999, 100, 39-64. [CrossRef]

14. Hanson, J.R. Prosperity and Economic Freedom. Indep. Rev. 2000, 4, 525-531.

15. Heckelman, J.C. Economic Freedom and Economic Growth: A Short-Run Causal Investigation. J. Appl. Econ. 2000, 3, 71-91.

16. Hall, J.; Lawson, R. Economic Freedom of the World: An Accounting of the Literature. Contemp. Econ. Policy 2014, 32, 1-19. [CrossRef]

17. Gwartney, J.D.; Lawson, R.; Block, W. Economic Freedom of the World, 1975-1995; Fraser Institute: Vancouver, BC, Canada, 1996.

18. Carlsson, F.; Lundstrom, S. Economic Freedom and Growth: Decomposing the Effects. Public Choice 2002, 112, 335-344. [CrossRef]

19. Scully, G.W. Economic Freedom, Government Policy and the Trade-Off between Equity and Economic Growth. Public Choice 2002, 113, 77-96. [CrossRef]

20. Hafer, R.W. Economic Freedom and Financial Development: International Evidence. Cato J. 2013, 33, 111-126.

21. Pal, S.; Dutta, N.; Roy, S. Media Freedom, Socio-Political Stability and Economic Growth. Available online: http:/ / esnie.org/pdf/textes_2011/Dutta-Media-Freedom (accessed on 26 September 2011).

22. Williamson, C.R.; Mathers, R.L. Economic freedom, culture, and growth. Public Choice 2011, 148, $313-335$. [CrossRef]

23. Doucouliagos, C.; Mehmet, A.U. Economic freedom and economic growth: Does specification make a difference? Eur. J. Polit. Econ. 2006, 22, 60-81. [CrossRef] 
24. Kutner, M.H.; Nachtsheim, C.J.; Neter, J. Applied Linear Regression Models, 4th ed.; McGraw-Hill Irwin: NYC, NY, USA, 2004.

25. Index of Economic Freedom. Available online: http://en.wikipedia.org/wiki/Index_of_Economic_ Freedom_ranking (accessed on 23 March 2016).

26. Global and Regional Developments. Available online: http://www.heritage.org/index/book/chapter-6 (accessed on 23 March 2016).

27. Methodology. Available online: http://www.heritage.org/index/book/methodology (accessed on 23 March 2016).

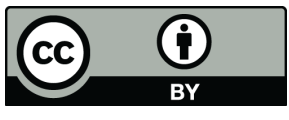

(C) 2016 by the authors; licensee MDPI, Basel, Switzerland. This article is an open access article distributed under the terms and conditions of the Creative Commons by Attribution (CC-BY) license (http://creativecommons.org/licenses/by/4.0/). 